Article

\title{
Dynamic Simulation and Thermoeconomic Analysis of a Hybrid Renewable System Based on PV and Fuel Cell Coupled with Hydrogen Storage
}

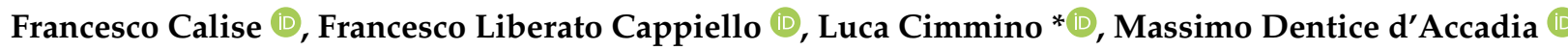 \\ and Maria Vicidomini
}

check for updates

Citation: Calise, F.; Cappiello, F.L.; Cimmino, L.; Dentice d'Accadia, M.; Vicidomini, M. Dynamic Simulation and Thermoeconomic Analysis of a Hybrid Renewable System Based on PV and Fuel Cell Coupled with Hydrogen Storage. Energies 2021, 14 , 7657. https://doi.org/10.3390/ en14227657

Academic Editor: Vladislav A. Sadykov

Received: 8 October 2021

Accepted: 8 November 2021

Published: 16 November 2021

Publisher's Note: MDPI stays neutral with regard to jurisdictional claims in published maps and institutional affiliations.

Copyright: (c) 2021 by the authors. Licensee MDPI, Basel, Switzerland. This article is an open access article distributed under the terms and conditions of the Creative Commons Attribution (CC BY) license (https:// creativecommons.org/licenses/by/ $4.0 /)$.
Department of Industrial Engineering, University of Naples Federico II, 80125 Naples, Italy; frcalise@unina.it (F.C.); francescoliberato.cappiello@unina.it (F.L.C.); dentice@unina.it (M.D.d.); maria.vicidomini@unina.it (M.V.)

* Correspondence: luca.cimmino@unina.it
Abstract: The production of "green hydrogen" is currently one of the hottest topics in the field of renewable energy systems research. Hydrogen storage is also becoming more and more attractive as a flexible solution to mitigate the power fluctuations of solar energy systems. The most promising technology for electricity-to-hydrogen conversion, and vice versa, is the reversible solid-oxide cell (SOC). This device is still very expensive, but it exhibits excellent performance under dynamic operating conditions compared to the competing devices. This work presents the dynamic simulation of a prototypal renewable plant combining a $50 \mathrm{~kW}$ photovoltaic (PV) field with a $50 \mathrm{~kW}$ solid-oxide electrolyzer cell (SOEC) and a compressed hydrogen tank. The electricity is used to meet the energy demand of a dwelling located in the area of Campi Flegrei (Naples). The SOC efficiency is simulated by developing a mathematical model in MATLAB ${ }^{\circledR}$. The model also calculates the cell operating temperature as a function of the input current. Once the optimal values of the operating parameters of the SOC are calculated, the model is integrated in the transient system simulation tool (TRNSYS) for dynamic analysis. Furthermore, this work presents a parametric analysis of the hydrogen storage system (HSS). The results of the energy and environmental analyses show that the proposed system can reach a primary energy saving by $70 \%$ and an amount of saved $\mathrm{CO}_{2}$ of 28 tons/year. Some possible future market scenarios are considered for the economic analysis. In the most realistic case, the optimal configuration shows a simple pay back lower than 10 years and a profit index of $46 \%$.

Keywords: solid-oxide cell; green hydrogen; photovoltaic; hydrogen storage system; renewable energies; dynamic analysis

\section{Introduction}

In recent years, more and more attention has been paid to the energy conversion issue. As a matter of fact, the effects of greenhouse gas (GHG) emissions on the climate are more alarming than ever [1]. As the demand for energy is ever increasing, the optimization of energy system is mandatory to address the climate change issue. Optimization of energy systems does not only mean replacing fossil sources with renewable ones, such as solar, wind, or geothermal. It also means improving the distribution and the storage of the energy to improve the renewable energy well [2]. Furthermore, solar and wind sources are extremely fluctuating, also determining a corresponding variation of their electricity production [3]. Thus, the use of suitable energy storage systems is mandatory to mitigate these fluctuations. Moreover, the use of suitable energy storage systems also allows one to avoid local grid overloading during the most irradiated or windy hours [4].

In this framework, hydrogen is becoming increasingly attractive as energy vector owing to the variety of processes it can be part of [5]. Since hydrogen does not exist in nature in its pure form, it is commonly produced by converting hydrocarbons or water. 
Currently, two main techniques are available. The first one is hydrogen production from electricity by means of the electrolysis process [6]. In this case, electricity must come from a renewable source, and the final product is called "green hydrogen" [7]. The second one, which is fairly disputed, is hydrogen production from hydrocarbons (mainly natural gas), also known as "blue hydrogen" [8].

Recently, interesting economic assessments about hydrogen production from steam methane reforming (SMR) were proposed [9]. Solutions that are intermediate between "blue" and "green" hydrogen production also are studied [10].

"Green hydrogen" shows better environmental performance since no $\mathrm{CO}_{2}$ is produced but it suffers from higher costs [11]. Thapa et al. [12] studied the potentials of hydrogen production from hydropower plants in Nepal aiming to replace fossil fuels in road transport sector. An estimation of the surplus energy in the years to come was made relying on current data from the national authority. For the analysis, the surplus electricity produced by hydropower plants was assumed to be exploited. Results showed that by only considering $80 \%$ of the total surplus electricity for the year 2027, more than 1.2 million $\mathrm{kL}$ of gasoline could be replaced by hydrogen. In a recent work, Rabiee et al. [13] assessed the technical barriers for the "green hydrogen" harnessing. To quantify the impact of voltage security constraints, they developed a non-linear model validated on the Institute of Electrical and Electronics Engineers (IEEE) 39 bus system. Through the analysis of the most influential technical factors, it resulted that the power to hydrogen $(\mathrm{P} 2 \mathrm{H})$ system location, the loadability constraints, and the renewable energy source (RES) penetration strongly affect the "green hydrogen" exploitability. In addition, the results showed that the location of the $\mathrm{P} 2 \mathrm{H}$ plants strongly depends on the RES penetration in a given area. Wind turbine technology in particular was analyzed for $\mathrm{P} 2 \mathrm{H}$ demand. It resulted that, for a value of wind penetration of $30 \%$ or lower, the $\mathrm{H}_{2}$ demand is critically influenced by the load margin factor.

The most-quoted technique for hydrogen production is electrolysis due to the too-low efficiency/cost ratio of thermochemical and photocatalytic processes [14]. Moreover, under dynamic operating conditions, SOCs are preferable to proton exchange membrane (PEM) or alkaline electrolyzer cell (AEC) [15].

Studies on the dynamic operation of PV systems with reversible SOCs are still lacking in the literature. Indeed, the majority of the papers is still focused on the use of PEM or AEC. Wang et al. [16] proposed an energy and exergy analysis of a hybrid system including $\mathrm{PV}$, an alkaline fuel cell (AFC) and a Stirling engine for electricity and heat production, and an absorption chiller for cooling energy production. Results showed that a $6.76 \mathrm{~kW}$ PV field, a $1 \mathrm{~kW} \mathrm{AFC,} \mathrm{and} \mathrm{a} 0.73 \mathrm{~kW}$ Stirling engine produce, in nominal conditions, $3.42 \mathrm{~kW}$ of electricity and $0.91 \mathrm{~kW}$ of cooling power. The electricity provided by the PV field accounts for almost $50 \%$ of the total electricity produced by the studied plant. In fact, AFC and the Stirling cycle are mainly used for cooling purposes. The electric and overall efficiency of the proposed system are $64.34 \%$ and $77.57 \%$, respectively. Finally, an exergy analysis is also carried out, assessing that the studied power plant is featured by $77.44 \mathrm{~kW}$ of exergy destruction. Holmes-Gentle et al. [17] developed a nonlinear model to investigate the functioning of a hybrid system including concentrated $\mathrm{PV}(\mathrm{CPV})$ panels with PEM fuel cells and other auxiliary components. The size of the cell is $2 \mathrm{~kW}$. The system is modeled by means of mass and energy balances and the dynamic simulation is carried out in gPROMS. The proposed system is exploited for fuel and thermal energy production. CPV water flowrate and solar irradiance were selected as the parameters to be ranged during the simulation of the nonlinear response of the system. Results from the simulation showed that the operating temperature of the components had a linear response. In contrast, electric components of the CPV and PEM showed a nonlinear behavior.

Cao et al. [18] developed a multi-objective parametric analysis of a PV-integrated SOEC/SOFC system for "green hydrogen" production. In the case study, the plant is sized considering the SOFC electricity demand, and the surplus hydrogen is sold. The parametric analysis was carried out by varying some of the main parameters such as the 
current density of the cells or the surplus hydrogen produced. A comprehensive energy, exergy, and economic model was also developed. Results showed an $\mathrm{H}_{2}$ overproduction four times higher than the demand. In this case, the simple pay back (SPB) drops below 7 years. Furthermore, the higher the density current of the cell, the lower the efficiency of the cell. Martin-Garcia et al. [19] proposed a techno-economic feasibility study of a fuel cell coupled with PV for "green hydrogen" production. The system satisfies the electricity demand of a dwelling, and the surplus hydrogen is stored inside a tank. The analysis is carried out by means of Homer Energy Pro tool, which is useful for the components design. Results showed that a $55 \mathrm{~kg}$ capacity storage is suitable for the exploitation of $2 \mathrm{PV}$ field of $8 \mathrm{~kW}$ of rated power, coupled with a $7.2 \mathrm{~kW}$ SOEC. As expected, the double conversion from electricity to hydrogen and vice versa determines a low overall efficiency since $4 \mathrm{kWh}$ of PV electric energy are required to satisfy $1 \mathrm{kWh}$ of load demand. Al-Khori et al. [20] recently proposed an economic analysis comparing a PV system with electric storage and a PV system coupled with SOFC. The PV size was selected equal to $33.5 \mathrm{MW}$. Both systems were compared in order to meet the electricity demand of a gas processing plant. Results from the economic analysis showed that the PV-SOFC system has a levelized cost of energy ( $L C O E)$, on a 25 year basis, of $0.11 \mathrm{US} \$ / \mathrm{kWh}$. The PV with electric storage system has a LCOE equal to $0.16 \mathrm{US} \$ / \mathrm{kWh}$, so the SOFC integrated system is more convenient. Moreover, the PV-SOFC system showed a net present value (NPV) of 5 million US\$.

A large research effort has been performed for the investigation of the hydrogen as energy vector. A similar effort is also performed to analyze hydrogen as an energy storage system [21]. Recently, Okundamiya [22] proposed a parametric analysis of the optimal size of a hybrid system including PV/SOC and hydrogen storage. The system must satisfy the electricity demand of a university laboratory. Hourly simulation performed with HOMER showed that the optimal configuration includes a $54.7 \mathrm{~kW}$ PV field, $3 \mathrm{~kW}$ electrolyzer, $7 \mathrm{~kW}$ fuel cell, and $8 \mathrm{~kg}$ hydrogen storage. The renewable fraction of the total load is $96.7 \%$, and the cost of energy (COE) is $0.0418 \$ / \mathrm{kWh}$.

Hydrogen production and storage are also considered for nuclear power hybrid systems. This is due to the high temperature steam released as a consequence of reactor cooling [23]. Ho et al. [24] proposed an innovative nuclear hybrid energy system (NHES) with a steam Rankine cycle, an electrolyzer, a hydrogen storage in a salt cavern, and a Brayton cycle for an additional electricity production. All the mentioned components are described by means of a dynamic mathematical model. In particular, the modeling of the salt cavern is interesting since this is an innovative and effective solution for hydrogen storage [25]. Results showed that the proposed system satisfies the annual grid demand by $93 \%$. The hydrogen production and storage system led to a decrease of the plant loads and improved its flexibility.

\section{Aim and Novelty of the Study}

The aim of the paper is to present a dynamic analysis of a hybrid renewable plant that exploits the electricity provided by a PV field to match the power demand of a dwelling. The surplus electricity is supplied to a SOEC system to convert it into hydrogen and store it inside a carbonium-fiber tank. The energy storage allows one to avoid overloads of the electric grid at the local level during the most irradiated hours. Furthermore, the energy stored can be exploited when a deficit of PV production occurs. In that case, hydrogen is withdrawn from the tank and sent to a SOFC system to furnish the needed energy.

As above noted, there is a lack of studies in the literature dealing with the dynamic simulation of PV systems coupled with solid-oxide fuel cells. Several studies handle the hydrogen storage issue for the mitigation of energy fluctuations. However, only a few of these works focus on the dynamic analysis of hydrogen hybrid renewable systems [26]. Thus, to the best of the authors' knowledge, there is still a lack of works dealing with the dynamic analysis of green hydrogen production systems. The novelty of this work can be summarized by the following points: 
- The dynamic analysis of a hybrid renewable system for hydrogen production and storage is carried out by means of a reversible SOC model validated in MATLAB ${ }^{\circledR}$;

- Several control strategies are implemented and discussed both for the operation of the fuel cell and hydrogen storage; furthermore, temperature operating conditions of the cell are managed;

- A well-developed thermoeconomic analysis is proposed to evaluate the energy and environmental savings along with the economic feasibility;

- A thermoeconomic analysis focused on the hydrogen storage is made to select the optimal size of the $\mathrm{H}_{2}$ storage for the proposed system;

- The analysis of the power exchanged with the grid is carried out to investigate how the local grid overloading conditions are avoided by means of the proposed technology.

\section{Solid-Oxide Cell Model}

The SOC mathematical model proposed in this work is a lumped-parameter model, presented by Wang et al. [27]. Although several SOC models are available in the open literature, only a few of them are suitable for being integrated in a dynamic simulation. The need to develop an in-house simulation model of the reversible solid-oxide cell comes from the lack of models available in the TRNSYS built-in library. On the other hand, other components are suitably modeled in TRNSYS, as will be shown in the next section, but no model is available for the SOC. The mathematical modeling of the SOC is an interdisciplinary task because it involves different research areas. In fact, a well-structured model must include an electrochemical model, a thermodynamic model, and a chemical reaction model [28]. Several phenomena have to be considered, such as transport and diffusion, heat and mass transfer, and chemical kinetics [29]. Obviously, the wider the model, the more accurate the simulation. The models available in the literature range from OD to 3D analysis; the latter are mainly developed in ANSYS or COMSOL [30].

The accuracy of the SOC model is not the main concern for the aim of the proposed work. The developed model of the SOC must be integrated in a more general dynamic system that undergoes a one-year simulation. To avoid excessive computational efforts, a $0 \mathrm{D}$ quasi-steady state model was selected because a more complex one would determine unacceptable computational times. The model considered in this work was validated by experimental studies, and it allows one to calculate the efficiency, voltage, and operating temperature of the cell starting from the input current. These parameters affect the polarization curve of the cell, which correlates the voltage to the current density. The polarization curve also depends on several design parameters such as geometry, pressure, fuel utilization factor, etc.

In SOFC mode, the cell operating voltage can be calculated starting from the reversible potential of the cell and subtracting the activation, ohmic, and concentration losses, as shown by the Nernst' law [31]

$$
V_{\text {cell }}=V_{\text {rev }}-V_{\text {act }}-V_{\text {ohm }}-V_{\text {conc }}
$$

Conversely, in SOEC mode, the mentioned losses represent an overvoltage that must be overcome to start the electrolysis process. Thus, terms must be added to the reversible potential

$$
V_{\text {cell }}=V_{\text {rev }}+V_{\text {act }}+V_{\text {ohm }}+V_{\text {conc }}
$$

Since more cells are electrically arranged in series to form a stack, the total voltage of the stack is the sum of all the cells' voltages. Considering that all the cells are equal

$$
V_{s}=N \cdot V_{\text {cell }}
$$


The reversible voltage, $V_{\text {rev }}$, is calculated starting from the Gibbs free energy of the reaction at standard conditions, which is a known parameter, according to the Nernst' equation [32]

$$
V_{\text {rev }}=\frac{-\Delta G_{0}}{2 F}+\frac{R T}{2 F} \ln \left(\frac{p_{\mathrm{H}_{2}} \cdot p^{0.5} \mathrm{O}_{2}}{p_{\mathrm{H}_{2} \mathrm{O}}}\right)
$$

where $\Delta G_{0}$ is the Gibbs free energy at standard conditions ( $T=25^{\circ} \mathrm{C}, p=1$ bar) and $F$ is the Faraday constant. Moreover, to calculate $V_{\text {rev }}$ at the cell operating conditions, the operating temperature and the partial pressures of the gases must be also considered.

The activation losses are due to the charge transfer between electronic and ionic conductors and represent an energy barrier that must be overcome to activate the electrolysis process. This term is calculated by means of the semiempirical Butler-Volmer equation

$$
i=i_{0}\left[\exp \left(\frac{\alpha F V_{a c t}}{R T}\right)-\exp \left(\frac{-(1-\alpha) F V_{a c t}}{R T}\right)\right]
$$

where $i$ is the density current, $\alpha$ is the symmetry factor, and $i_{0}$ is the exchange current, calculated as

$$
i_{0}=\gamma \exp \left(-\frac{E_{a c t}}{R T}\right)
$$

where $E_{\text {act }}$ is the activation energy. The ohmic losses depend on the ohmic resistance of the electrons and ions flows through the components and the connectors. It can be calculated as

$$
V_{\text {ohm }}=i \cdot A S R_{\text {ohm }}
$$

where $A S R_{\text {ohm }}$ is the area-specific ohmic resistance, which is function of the materials adopted and the operating temperature, empirically correlated.

The concentration losses depend on the concentration gradient between the bulk flow and the reaction sites. In fact, because the electrochemical reactions occur at the "three phases boundary", a mass transport phenomenon within the electrodes takes place. To model the diffusion losses that are caused by this phenomenon, the Fick's law was selected, which implies less computational effort. According to this law, the concentration losses are calculated as follows:

$$
V_{\text {conc }}=\frac{R T}{z F} \ln \left(1-\frac{i}{i_{l}}\right)
$$

where $i_{l}$ is the limiting current density, given from the cell datasheet.

The operating current $I$ is instead obtained by means of the fuel utilization factor $U_{f}$

$$
I=2 U_{f} \cdot n_{H_{2}}
$$

Because the current is an input of the model, the hydrogen produced, or required, by the cell is the result of the equation. The oxygen flow rate is calculated by means of the air utilization factor $U_{a}$

$$
n_{\mathrm{O}_{2}}=\frac{U_{f} \cdot n_{H_{2}}}{2 U_{a}}
$$

Once the cell voltage and the molar fluxes are calculated, the operating temperature is obtained as a function of the equilibrium constant

$$
K\left(T_{\text {cell }}\right)=\frac{n_{H_{2} \mathrm{O}}^{\text {out }}}{n_{\mathrm{O}_{2}}^{\text {out }} \cdot n_{\mathrm{H}_{2}}^{\text {out }}}
$$

The overall efficiency of the process is defined as the ratio between the electric energy provided by the SOFC, $E_{e l, S O F C}$, and the electric energy supplied to the SOEC, $E_{e l, S O E C}$ 


$$
\eta_{g l o b}=\frac{E_{e l, S O F C}}{E_{e l, S O E C}}
$$

\section{System Model}

\subsection{TRNSYS Model}

From the reversible SOC mathematical model developed in MATLAB ${ }^{\circledR}$, it is possible to determine the production/demand of hydrogen given the current as input of the model. This model can be integrated in TRNSYS environment to simulate the dynamic behavior of a hybrid renewable system.

TRNSYS is a software diffusely used in the transient analysis and for the dynamic simulation of several energy systems [33]. Energy components are called "types", each of them representing an interface of a built-in mathematical model. For the proposed case study, the following main components are used for the dynamic simulation, namely SOC, $\mathrm{H}_{2}$ storage, $\mathrm{H}_{2}$ compressor, and PV field. A number of additional components are also included in the project (controllers, mixers, diverters, printers, data readers, integrators, etc.). The SOC model was presented in the previous section. As for the models of the other components, a brief description is provided below:

- The PV field component is modeled by means of type94, which considers an equivalent electric circuit to determine the $I-V$ curve of a PV module [34]. Solar radiation is given from another type, which uses data from METEONORM database [35]. This type is set in order to track the maximum power point (MPP). The electric power produced by the PV field is supplied to a DC/AC (direct current-alternate current) inverter to meet the electric load of the dwelling.

- The hydrogen storage is modeled by means of type164, which considers an ideal gas storage model. The volumetric flow rate of hydrogen entering and exiting the tank is evaluated in $\mathrm{Nm}^{3}$ (273.15 K and $1 \mathrm{bar}$ ); the same unit is used for the volume of gas stored. To simplify the model, the gas is supposed to be compressed inside the tank by neglecting the corresponding temperature increase cause.

- The hydrogen compressor is modeled by the authors by means of standard mechanical equations for the calculation of the compression work. The outlet temperature is

$$
T_{\text {out }}=T_{\text {in }} \cdot \beta^{\frac{\lambda-1}{\lambda}}
$$

where $T_{\text {in }}$ is the inlet temperature; $\beta$ is the compression ratio, in this case, the ratio between the tank pressure and the ambient pressure; and $\lambda$ is the polytropic exponent, which is equal to 1.4 for the $\mathrm{H}_{2}$ since it is a diatomic gas [36].

\subsection{Thermoeconomic Model}

For the feasibility analysis of the proposed system, some common energy, environmental, and economic indexes are used. For the energy analysis, the primary energy saving (PES) of the proposed system with respect to the reference one is considered. For the sake of clarity, in the reference system, all the electricity load is supposed to be met by the national electric grid.

$$
\begin{gathered}
P E S=\frac{P E_{R S}-P E_{P S}}{P E_{R S}} \\
P E_{R S}=\frac{E_{e l, L O A D}}{\eta_{e l, r e f}} \\
P E_{P S}=\frac{E_{\text {el }, \text { fromG }}}{\eta_{\text {el }, \text { ref }}}-\frac{E_{\text {el, toGRID }}}{\eta_{\text {el, ref }}}
\end{gathered}
$$

where $\eta_{e l, r e f}$ is the efficiency if the electric grid, which is set equal to 0.46 for the Italian national grid.

Furthermore, for the energy analysis, the following energy ratios are defined:

$R_{\text {self }}=E_{\text {el, self }} / E_{\text {el,LOAD }}, R_{t o G R I D}=E_{e l, t o G R I D} / E_{e l, P V}, R_{\text {fromGRID }}=E_{e l, f r o m G R I D} / E_{e l, L O A D}$.

The previous terms are the fraction of self-consumed energy, the fraction of energy sent to the grid, and the fraction of energy withdrawn from the grid, respectively. For 
the environmental analysis, the total amount of avoided $\mathrm{CO}_{2}$ equivalent emissions is considered

$$
\begin{gathered}
\Delta \mathrm{CO}_{2}=\mathrm{CO}_{2, R S}-\mathrm{CO}_{2, P S} \\
\mathrm{CO}_{2, R S}=E_{l l, L O A D} \cdot f_{E E} \\
\mathrm{CO}_{2, P S}=E_{e l, \text { fromGRID }} \cdot f_{E E}
\end{gathered}
$$

where $f_{E E}$ is the $\mathrm{CO}_{2}$ equivalent emission factor for the electricity provided by the grid.

The thermoeconomic analysis is commonly based on the calculation of the $S P B$, which is a useful economic index to perform the feasibility analysis of a system [34]. This index is calculated as

$$
S P B=\frac{I N V_{T O T}}{\Delta C}
$$

where the numerator is the sum of the capital costs, and the denominator is the difference between operating costs of the reference and proposed system. These are calculated as follows

$$
\begin{gathered}
C_{R S}=E_{e l, L O A D} \cdot C_{u, E E} \\
C_{P S}=E_{e l, f r o m G R I D} \cdot C_{u, E E}-E_{e l, t o G R I D} \cdot P_{u, E E}
\end{gathered}
$$

where $C_{u, E E}$ is the unit cost of the electric energy purchased from the grid, and $P_{u, E E}$ is the unit price of the electric energy sold to the grid. Other useful indexes for the economic analysis are the net present value $(N P V)$ and the profit index $(P I)$.

$$
\begin{gathered}
N P V=(A F \cdot \Delta C)-I N V_{\text {TOT }} \\
P I=\frac{N P V}{I N V_{T O T}}
\end{gathered}
$$

where $A F$ is the annuality factor and it is calculated on a lifetime of the system of 25 years and a discount factor by $5 \%$.

The cost of the PV is supposed to be equal to $1000 € / \mathrm{kW}$ peak [37]. The estimated cost of the reversible SOC is deduced from the work of Singh et al. [38]. In the current scenario of fuel cell spreading, a cost of $1000 € / \mathrm{kW}$ is considered, which is quite realistic for the next few years. For the $\mathrm{H}_{2}$ storage, the cost is obtained by several works in literature [39]. A cost of $500 € / \mathrm{kg}$ of stored hydrogen is the most realistic for a carbonium fiber 200 bar tank. Further information about costs is shown in Table 1.

Table 1. Thermoeconomic parameters.

\begin{tabular}{cccc}
\hline Parameter & Description & Value & Unit \\
\hline$j_{\text {elffromGRID }}$ & Unit cost of the electric energy & 0.18 & $€ / \mathrm{kWh}$ \\
$j_{\text {el, }, \text { oGRID }}$ & Unit sell price of the electric energy & 0.06 & $€ / \mathrm{kWh}$ \\
$f_{E E}$ & $\mathrm{CO}_{2}$ equivalent emission factor for the & 0.483 & $\mathrm{kgCO}_{2} / \mathrm{kWh}$ \\
$L H V_{H 2}$ & electric energy & 11.109 & $\mathrm{MJ} / \mathrm{Nm}^{3}$ \\
$C_{P V}$ & Hydrogen lower heating value & 1000 & $€ / \mathrm{kW}$ \\
$C_{S O C}$ & PV unit cost & 1000 & $€ / \mathrm{kW}$ \\
$C_{\text {storage }}$ & SOC unit cost & 5000 & $€ / \mathrm{kg}$ \\
\hline
\end{tabular}

\section{Case Study}

The system is designed to meet the electricity demand of a dwelling located in Fuorigrotta (Naples, south of Italy). The electric load of the selected building is evaluated according to the approach described in detail in [40]. Figure 1 shows the building model developed with the Sketchup plug-in of the TRNSYS software.

The result is a daily load profile that shows three peaks between 8:00 and 10:00, between 11:00 and 12:00, and between 16:00 and 18:00. The first and the second peak are about $40 \mathrm{~kW}$, whereas the last peak reaches $60 \mathrm{~kW}$, which is the maximum value of the load. Figure 2 shows the considered electric load. 


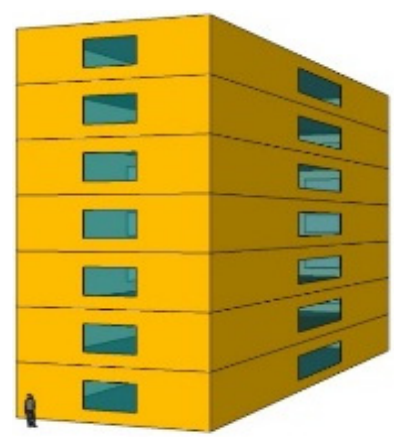

Figure 1. Building model.

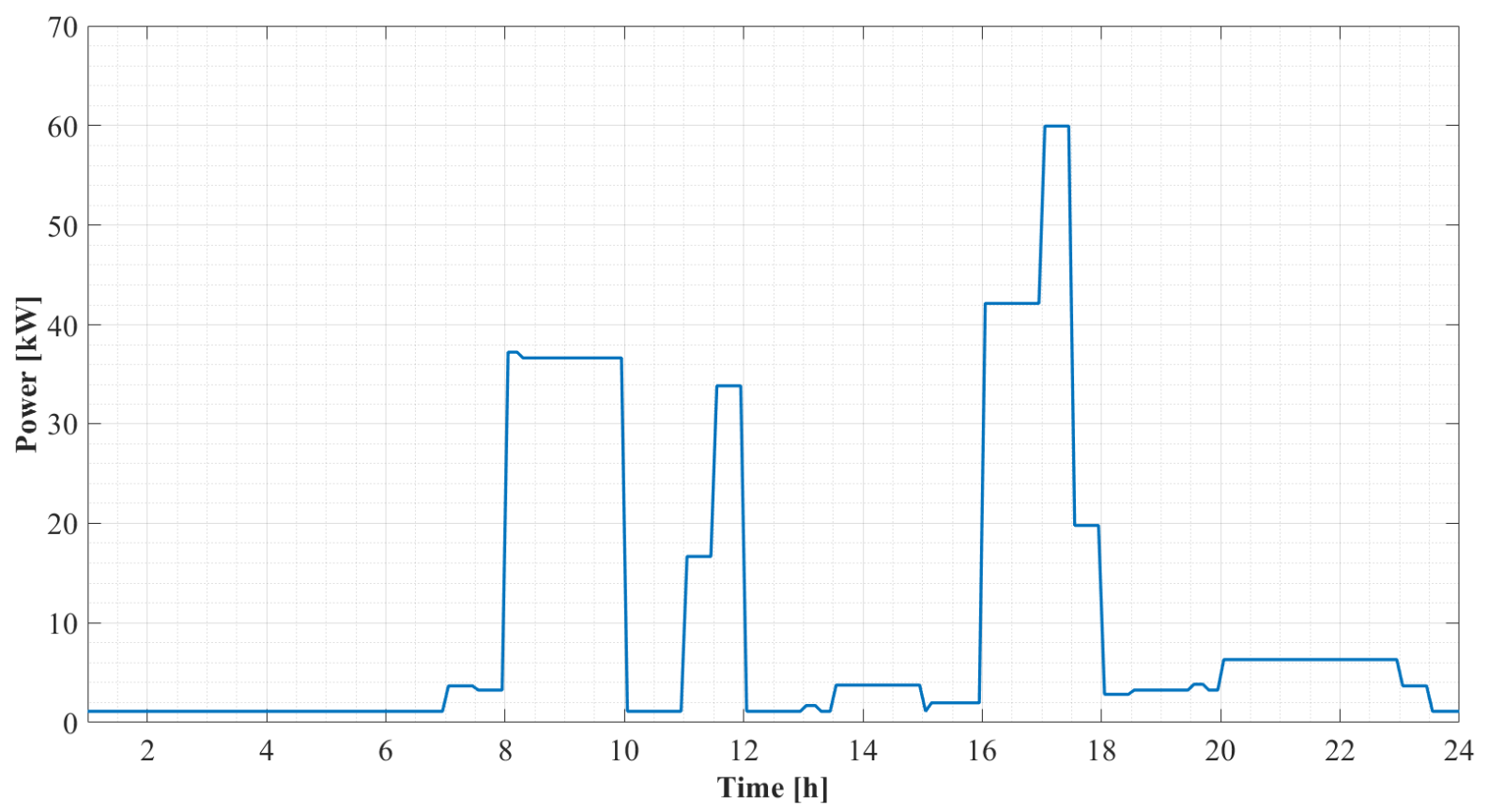

Figure 2. Layout of the system.

The reference system (RS) is the above-described dwelling, whose power load is met by the grid.

The layout of the proposed hybrid renewable plant is shown in Figure 3.

The layout mainly consists of two power circuits, the first on the end user side (UPC) and the second one on the SOC side (SPC), and a hydrogen circuit (HC). HC connects a $50 \mathrm{~kW} \mathrm{SOC}$ with a $1 \mathrm{~m}^{3}$ Hydrogen tank (TK), operating at a maximum pressure of 200 bar. The core of the whole system is the control unit (CU), which manages all the power fluxes among the load, PV system, SOC, and tank. Several control strategies are implemented in the $\mathrm{CU}$ to achieve a reliable and efficient operation of the system.

Firstly, the electricity provided by the PV is used to match the power load of the dwelling.

The available surplus power $\left(P_{\text {el, surplus }}\right)$, evaluated as the difference between $P_{e l, P V}$ and $P_{e l, L O A D}$, is delivered to the electrolyzer only if $P_{e l, \text { surplus }}$ is greater than or equal to the minimum activation power for the electrolyzer $\left(P_{e l, E C, \min }\right)$. Note that $\mathrm{CU}$ changes the current intensity and voltage of the incoming power according to SOEC polarization curve. Conversely, for values of $P_{\text {el,surplus }}$ lower than the minimum activation power, the electricity is directly supplied to the grid. Similarly, if the value of the $P_{\text {el,surplus }}$ is beyond the upper limit, the maximum suitable power is supplied to the SOEC, and the excess is exported to the grid. This operating strategy is used if the tank is full up to $95 \%$ (in terms of maximum pressure), otherwise the power is directly delivered to the grid. 


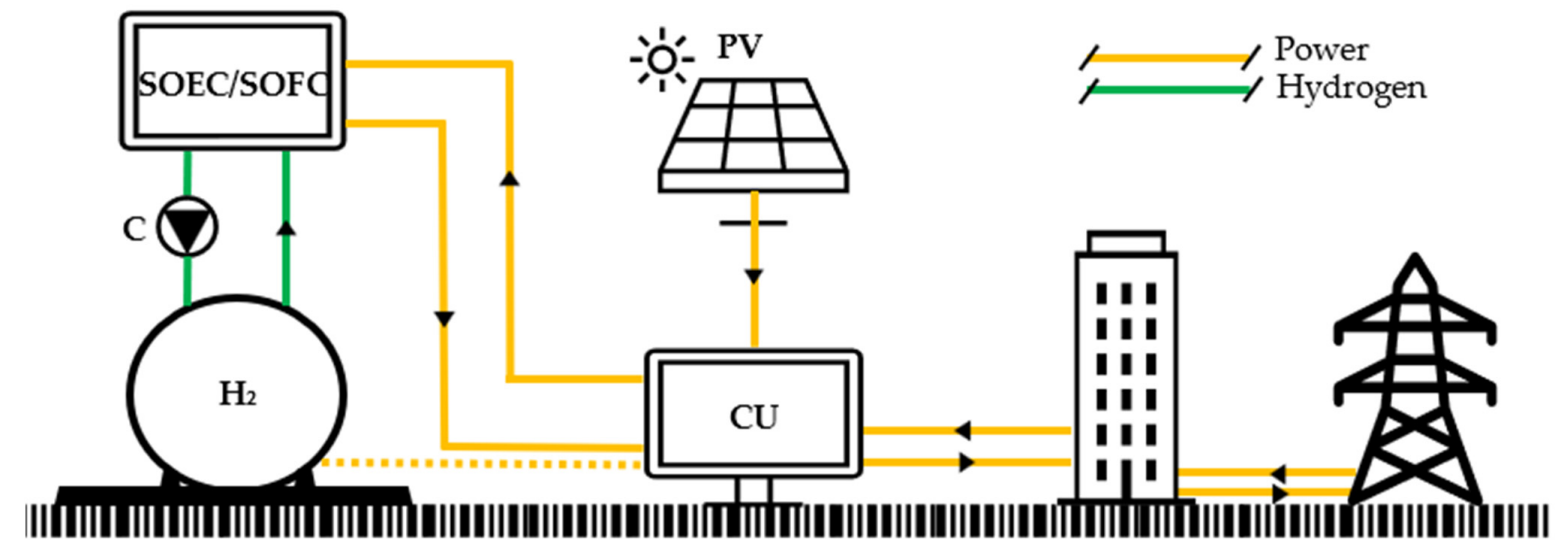

Figure 3. Layout of the system.

On the other hand, when $P_{e l, P V}$ is low or PV power production is null, the SOFC is activated, with the aim of matching $P_{e l, L O A D}$. The SOFC only operates when the output power required falls within the optimal range of operation for the cell. When the power required is below the lower limit $\left(P_{e l, F C, m i n}\right)$, the power is directly withdrawn from the grid. On the contrary, when the power required is beyond the cell upper limit $\left(P_{e l, F C, \text { max }}\right)$, the maximum power is met by the SOFC, and the residual $P_{\text {el,deficit }}$ is matched by the grid. No hydrogen is supplied by the tank if this is not at least $16 \%$ full. In Figure 4 , the flow charts of the control system are shown.
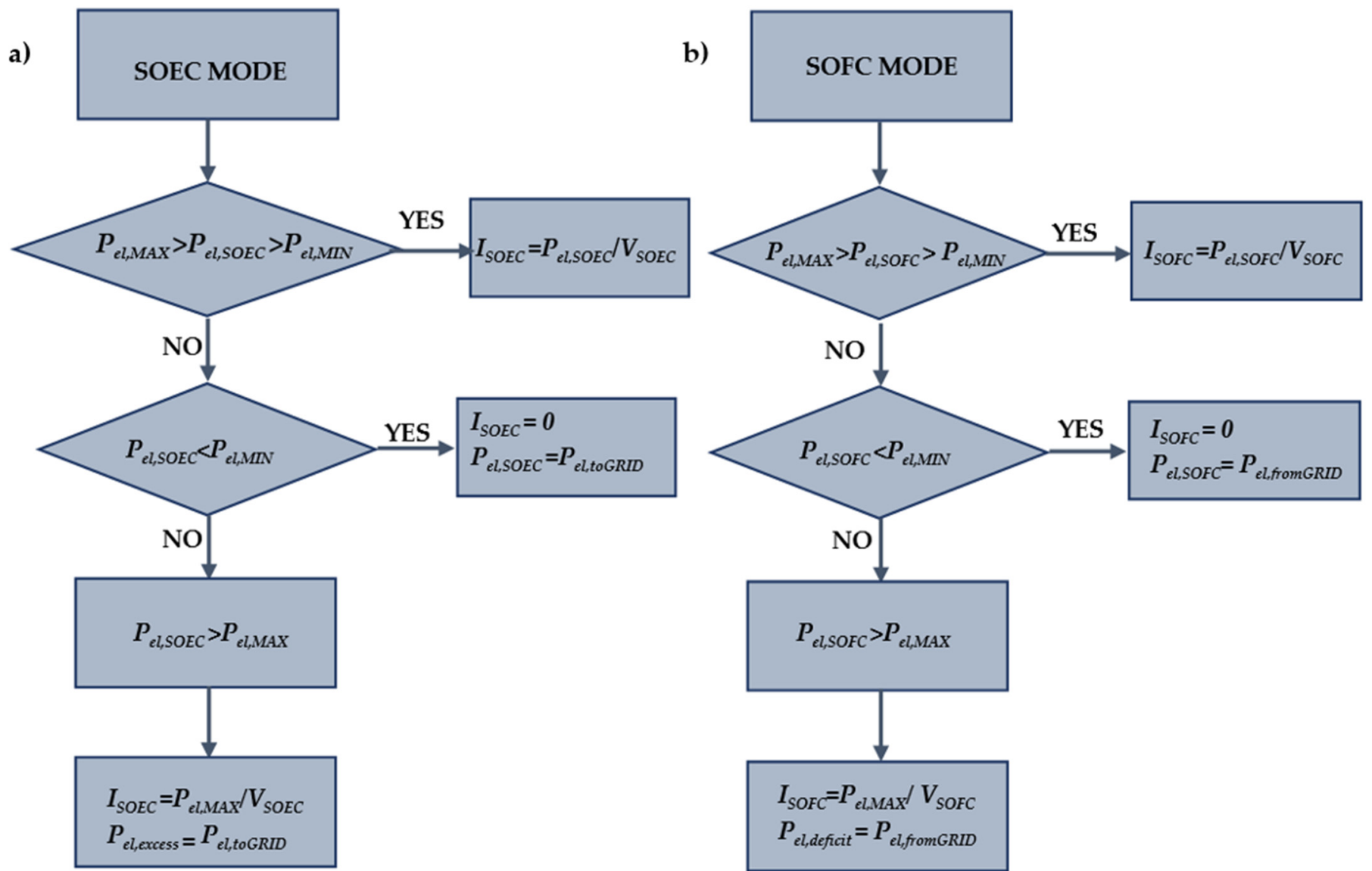

Figure 4. Flow chart of the feedback control for the electrolyzer (a) and the fuel cell (b).

Further design parameters of the model proposed are reported in Table 2. 
Table 2. System parameters.

\begin{tabular}{|c|c|c|c|c|}
\hline Component & Parameter & Description & Value & Unit \\
\hline \multirow{14}{*}{ PV PANEL } & $A_{\text {module } P V}$ & PV module area & 1.609 & $\mathrm{~m}^{2}$ \\
\hline & $P_{e l, P V}$ & PV field rated power & 50 & $\mathrm{~kW}$ \\
\hline & $N_{\text {series }}$ & Number of modules in series & 2 & $\cos$ \\
\hline & $N_{\text {paralel }}$ & Number of modules in parallel & 100 & \\
\hline & $I_{s c, r e f}$ & Module short-circuit current at reference conditions & 8.94 & A \\
\hline & $v_{o c, r e f}$ & Module open-circuit voltage at reference conditions & 37.3 & $\mathrm{~V}$ \\
\hline & $T_{c, r e f}$ & Reference temperature & 298 & $\mathrm{~K}$ \\
\hline & $G_{t o t, r e f}$ & Reference insolation & 1000 & $\mathrm{~W} / \mathrm{m}^{2}$ \\
\hline & $v_{m p, r e f}$ & Module voltage at max power point and reference conditions & 30.1 & V \\
\hline & $I_{m p, r e f}$ & Module current at max power point and reference conditions & 8.64 & A \\
\hline & $\mu_{I s c}$ & Temperature coefficient of $\mathrm{I}_{\mathrm{Sc}}$ at (ref. condition) & 0.0004 & \\
\hline & $\mu_{v o c}$ & Temperature coefficient of $\mathrm{v}_{\mathrm{OC}}$ (ref. condition) & -0.003 & $1 / \mathrm{K}$ \\
\hline & $T_{C, N O C T}$ & Module temperature at NOCT & 319 & \\
\hline & $T_{c, r e f}$ & Ambient temperature at NOCT & 293 & K \\
\hline \multirow{9}{*}{ Electrolizer-Fuel Cell } & $P r_{\text {cell }}$ & Cell operative pressure & 1 & bar \\
\hline & $A_{\text {cell }}$ & Cell area & 87.7 & $\mathrm{~cm}^{2}$ \\
\hline & $n_{\text {cell }}$ & Number of cells in series & 8 & - \\
\hline & $n_{\text {stack }}$ & Number of stacks in parallel & 50 & \\
\hline & $P_{\text {elECmin }}$ & Minimum power allowed to SOEC & 13.15 & $\mathrm{~kW}$ \\
\hline & $P_{e l, E C, \max }$ & Maximum power allowed to SOEC & 48.23 & $\mathrm{~kW}$ \\
\hline & $P_{e l, F C, \min }$ & Minimum power allowed from SOFC & 10.52 & $\mathrm{~kW}$ \\
\hline & $P_{e l, F C, \max }$ & Maximum power allowed from SOFC & 36.83 & $\mathrm{~kW}$ \\
\hline & $P_{e l, F C} / P_{e l, E C}$ & Rated fuel cell/electrolyzer capacity & $45 / 50$ & $\mathrm{~kW}$ \\
\hline \multirow{2}{*}{$\mathrm{H}_{2}$ storage } & $V$ & Tank volume & 1 & $\mathrm{~m}^{3}$ \\
\hline & $P r_{T K, \max }$ & Maximum tank pressure & 200 & bar \\
\hline Compressor & $\eta_{I S}$ & Compressor isentropic efficiency & 0.80 & - \\
\hline Inverter & $\eta_{I}$ & Inverter/Regulator efficiency & 0.96 & - \\
\hline
\end{tabular}

\section{Results and Discussion}

In this section, the results of both the SOC model validation against experimental data and the dynamic simulation of the hybrid system are presented and discussed. Subsequently, a parametric analysis of the $\mathrm{H}_{2}$ tank is proposed, and the optimal configuration is also discussed.

\subsection{SOC Model Validation}

The developed model was successfully validated by means of experimental data provided by the same authors [27]. In particular, the model proposes the simulation of a 50-stack planar cell designed and produced by Topsøe in 2014 made of Nickel/Yttria stabilized Zirconia (Ni/YSZ). Boundary operating conditions are reported in Table 3.

Table 3. Feeding condition for the experimental fuel cell [27].

\begin{tabular}{cccc}
\hline & Feeding Gas & Flow Rate & Temperature \\
\cline { 2 - 4 } & - & {$\left[\mathrm{sccm} / \mathrm{cm}^{2}\right]$} & {$[\mathrm{K}]$} \\
\hline Anode & $\mathrm{H}_{2} / \mathrm{H}_{2} \mathrm{O}(50-50 \%)$ & 12.44 & 1033 \\
Chatode & $\mathrm{O}_{2}(100 \%)$ & 5.70 & 1033 \\
\hline
\end{tabular}

As reported in this table, the anode is fed by a 50/50 mixture of hydrogen and steam whereas the cathode is fed by pure $\mathrm{O}_{2}$, when the cell operates in SOFC mode.

Figure 5 shows the comparison between the simulated $I-V$ curve of the cell and the experimental operating data, both for the electrolyzer and the fuel cell. 
a)

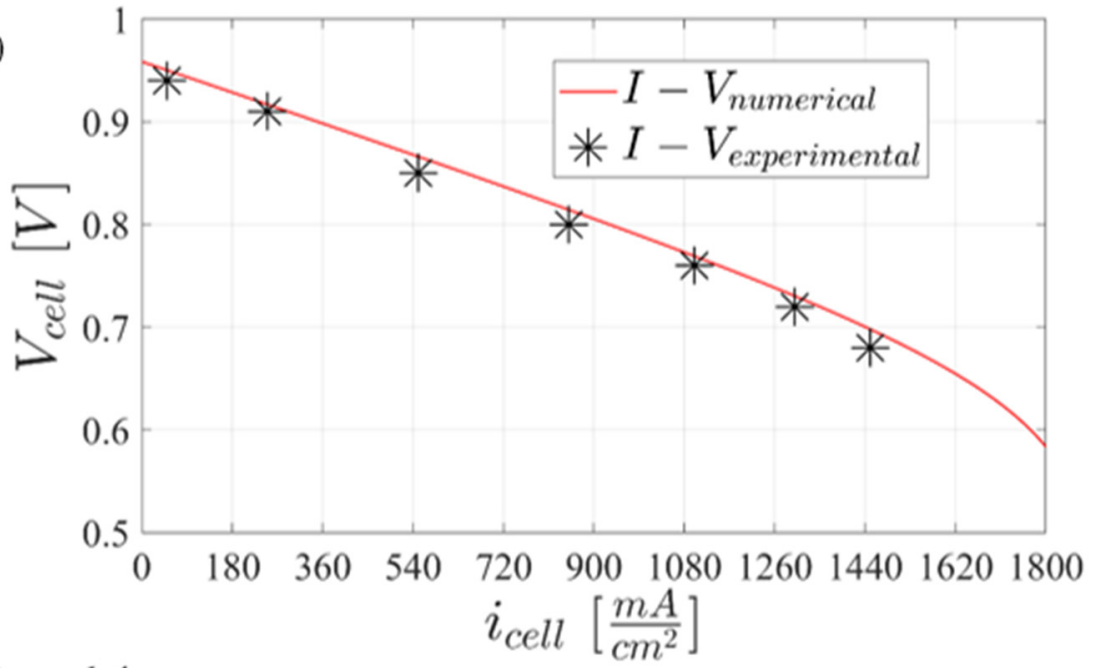

b)

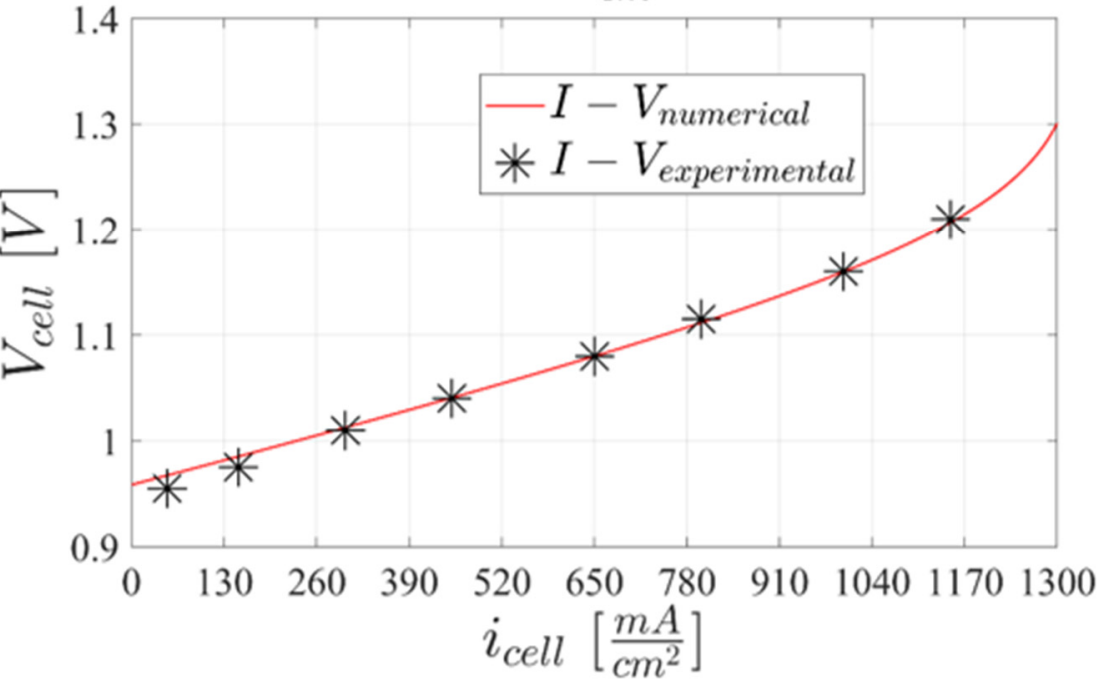

Figure 5. Comparison between numerical and experimental data for the fuel cell mode (a) and the electrolyzer mode (b).

There is a very good agreement between the experimental data and the polarization curves obtained by the model, for both configurations of the cell. The deviation between simulations and experiments is always below $2 \%$. The reported curves are also consistent with the previously described model. In fact, for the fuel cell, the voltage decreases in the case of higher current densities, whereas the opposite trend is detected for the electrolyzer.

Figure 6 shows the cell temperature as a function of the cell current density, $i_{\text {cell }}$, for different values of the fuel utilization factor. When the cell operates as a fuel cell, the higher the fuel utilization factor, the higher the temperature of the cell, whatever operating density current is considered. The result can be justified analyzing the energy balance. As a matter of fact, the higher the fuel utilization factor, the higher the amount of $\mathrm{H}_{2}$ reacting. As a consequence, in this case, a higher amount of heat is also released by the exothermic process.

On the other hand, when the cell operates as an electrolyzer, the opposite trend is detected as far as the density current is below a value of $854 \mathrm{~mA} / \mathrm{cm}^{2}$. In fact, as expected, the greater the reacting $\mathrm{H}_{2} \mathrm{O}$, the lower the cell temperature. This trend is due to the fact that these electrochemical reactions are endothermic. The temperature difference in this case is lower than the previous case, and it decreases to 0 when a value of current density of about $854 \mathrm{~mA} / \mathrm{cm}^{2}$ is reached. For higher values of the current density, the opposite trend occurs. The reason is that, in this case, the efficiency of the cell rapidly decreases due to the high operating temperature. Once the threshold value of current density is 
exceeded, the increasing of $\mathrm{H}_{2}$ production can no longer compensate for the increasing of absorbed power.

a)

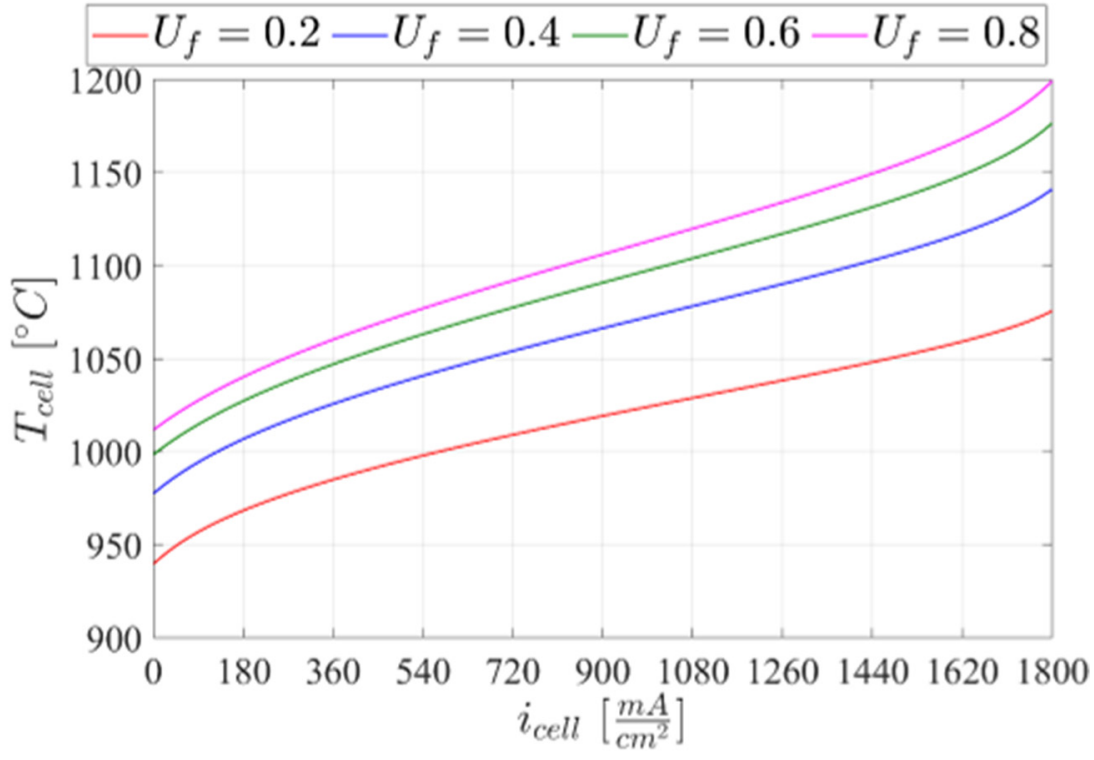

b)

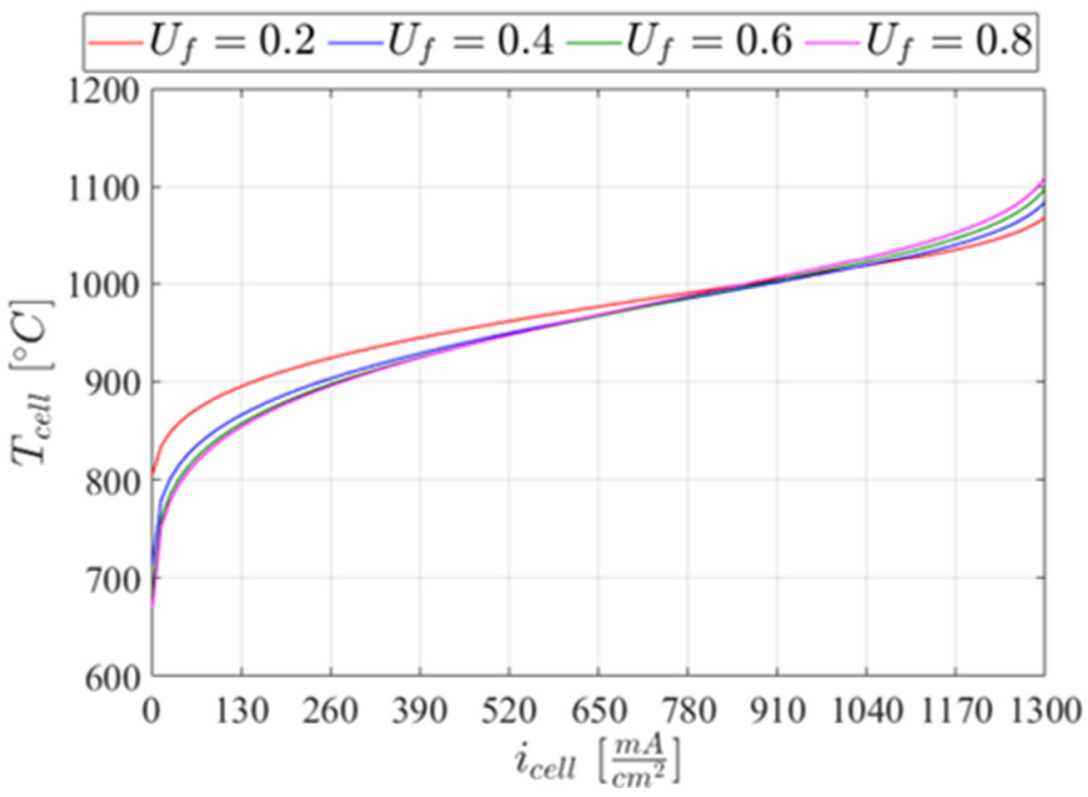

Figure 6. Temperature of the cell as a function of density current for different fuel utilization factors for the fuel cell mode (a) and the electrolyzer mode (b).

As a consequence, the cell should always operate in a specific range of current density to achieve an optimal operation. For values of this parameter out of the linear field of the polarization curve, the conversion efficiency is very low. Moreover, when the temperature of the cell is too high, the degradation of the cell occurs much faster. The selected current density range for the SOFC is between 400 and $1400 \mathrm{~mA} / \mathrm{cm}^{2}$, whereas for the SOEC, it is $300-1100 \mathrm{~mA} / \mathrm{cm}^{2}$. By means of the design parameters of the cell, it is possible to determine the range of electric power that can be supplied by the PV field or demanded by the load.

\subsection{TRNSYS Model Validation}

To evaluate the economic and transient energy performance of the proposed system, a dynamic simulation performed in TRNSYS environment is performed. Results are shown 
here and discussed on daily, monthly, and yearly basis. The tool returns the time-dependent behavior of the system for a 1-year operation. For sake of brevity, the following sections will analyze only one representative day. Furthermore, a parametric analysis on the hydrogen storage is performed to evaluate the optimal configuration of the proposed system.

\subsubsection{Daily Results}

Figure 7 shows the dynamic result of the transient simulation for the 31st of July, selected as a representative day to discuss the dynamic trends.

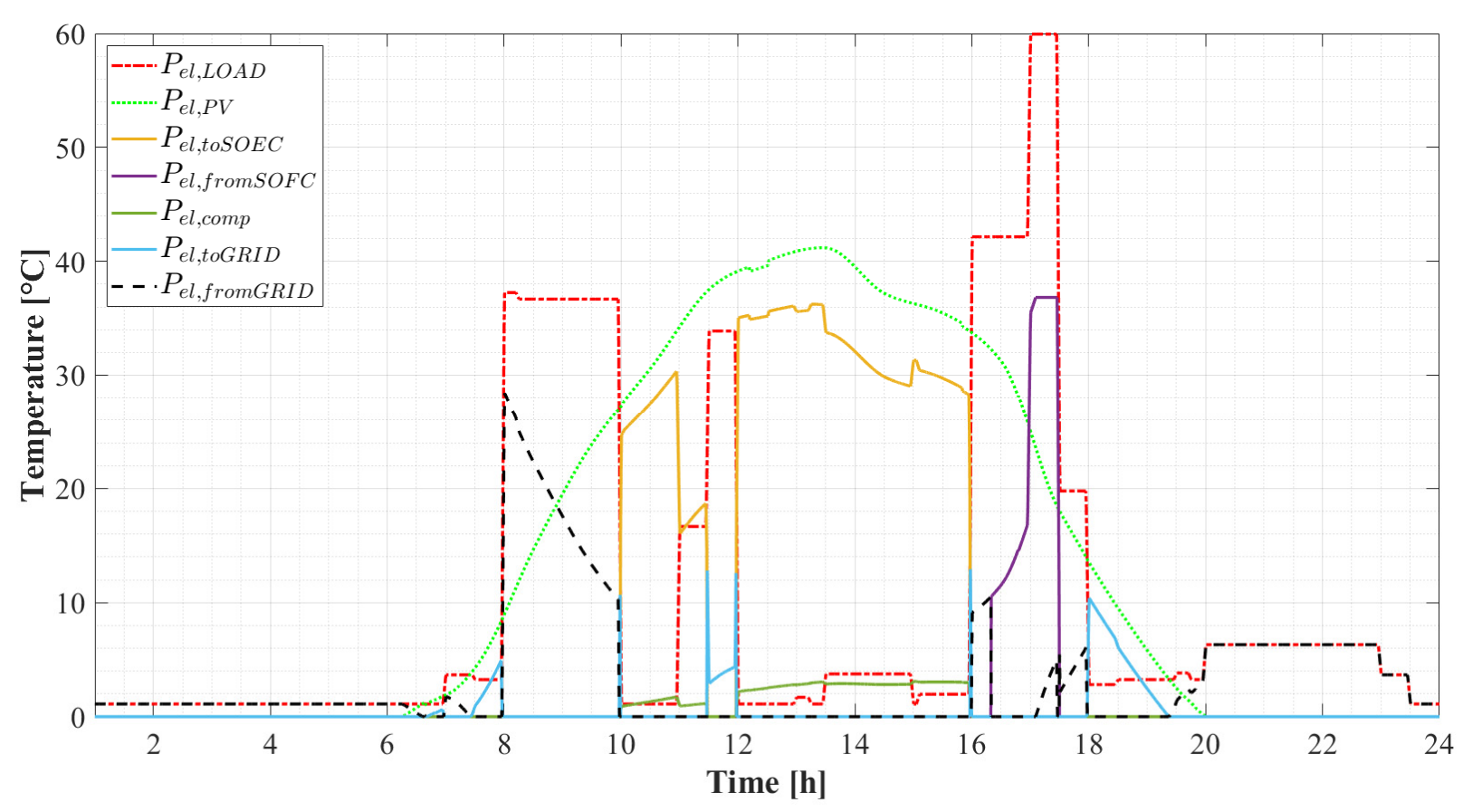

Figure 7. Dynamic results for the electricity transient analysis.

Here, the plot clearly shows the remarkable misalignment between the PV production, $P_{e l, P V}$, and the electric demand, $P_{e l, L O A D}$. This is justified by the fact that a residential electric load is considered. In fact, on the one hand, the peaks of the demand mainly occur in the first hours of the morning, between 8:00 and 10:00, and the evening, between 16:00 and 18:00. On the other hand, the solar radiation is maximum during the central hours of the day. Thus, this misalignment promotes the $\mathrm{H}_{2}$ production in the central hours of the day, between 10:00 and 16:00. The compression work, $P_{e l, c o m p}$, is not zero when the electricity is supplied to the SOEC, which means that the $\mathrm{H}_{2}$ is correctly supplied to the storage.

Before 8:00, the solar irradiation is almost null, and the PV power is equal to zero. Thus, the PV power is not used to match the load, and the electricity is directly supplied to the grid. The same behavior can be noticed after 18:00. These trends, beyond the climate conditions, are due to the feedback control included in the system, which does not allow the electricity to be supplied to the cell when its value is below the selected threshold value, as seen in Table 2. Since the selected day for the analysis is one of the most irradiated of the year, the PV field widely covers the load demand, and the $\mathrm{H}_{2}$ production is remarkably high. Despite this remarkable production of renewable power and renewable $\mathrm{H}_{2}$, the electricity withdrawn from the grid, $P_{\text {el,from } G R I D}$, is definitely not negligible. This trend is consistent with the selected control strategy; in fact, no $\mathrm{H}_{2}$ is withdrawn from the tank until its state of charge is at least $16 \%$. As a consequence, the SOFC is discharged for meeting the dwelling demand ( $P_{\text {elffromSOFC }}$ ) after 16:00 when the $\mathrm{H}_{2}$ tank is recharged. This means that, despite the remarkable production of hydrogen, the tank is only able to meet the load for a few hours. 


\subsubsection{Monthly Results}

Figure 8 shows the average results for each month of operation.

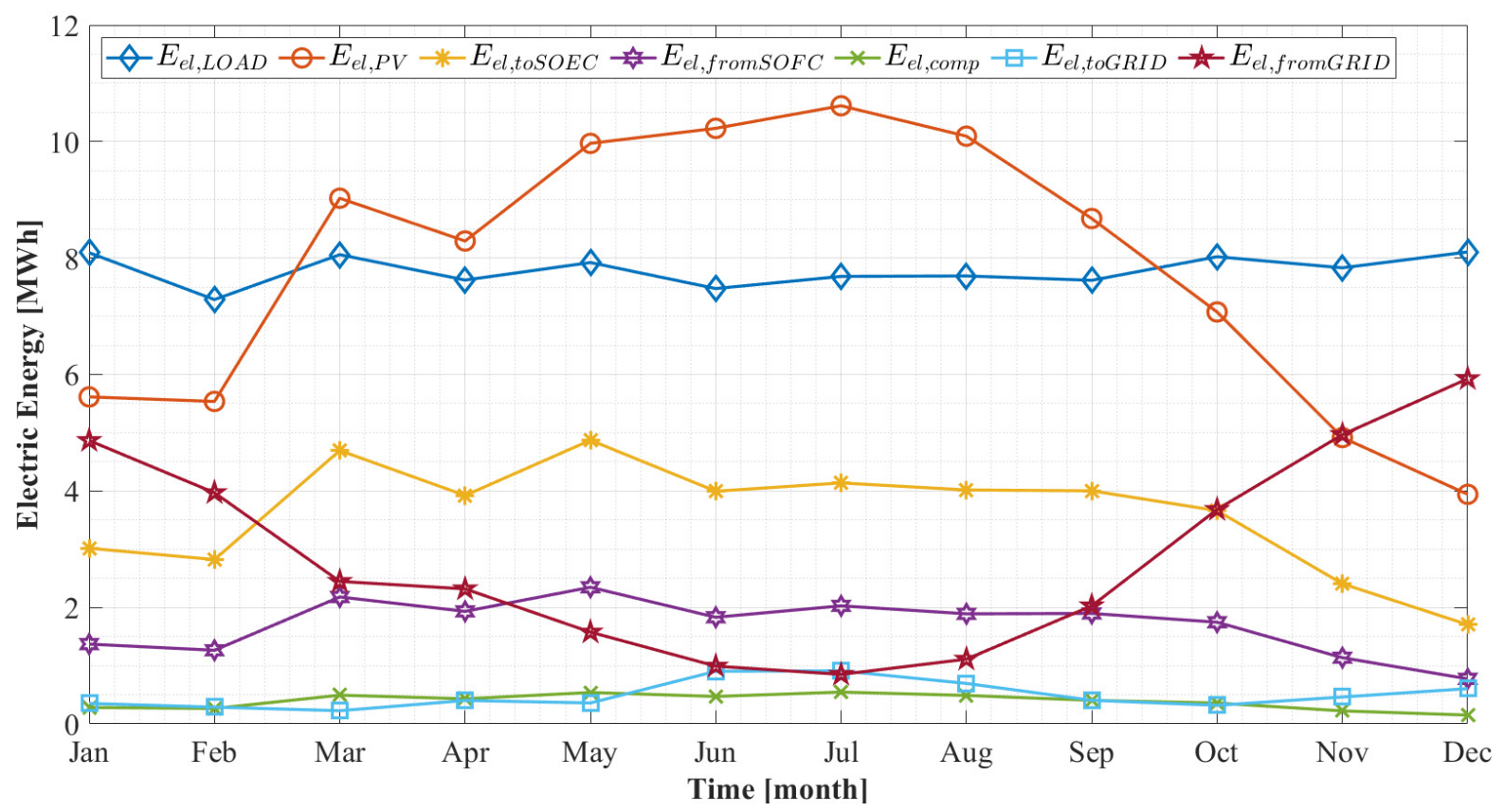

Figure 8. Monthly integration of the results from the dynamic analysis.

The results from the monthly analysis clearly show the advantage of using the SOC storage system with such a system. The previously described misalignment leads to a large use of the SOEC for $\mathrm{H}_{2}$ production and storage. As a matter of fact, during the summer season, the electric energy supplied by the grid, $E_{\text {elffromGRID }}$, decreases below $1 \mathrm{MWh} /$ month. In fact, the electricity withdrawn from the grid matches $10 \%$ of user electric energy demand during the month of July, as seen in $R_{\text {fromGRID }}$ in Figure 9.

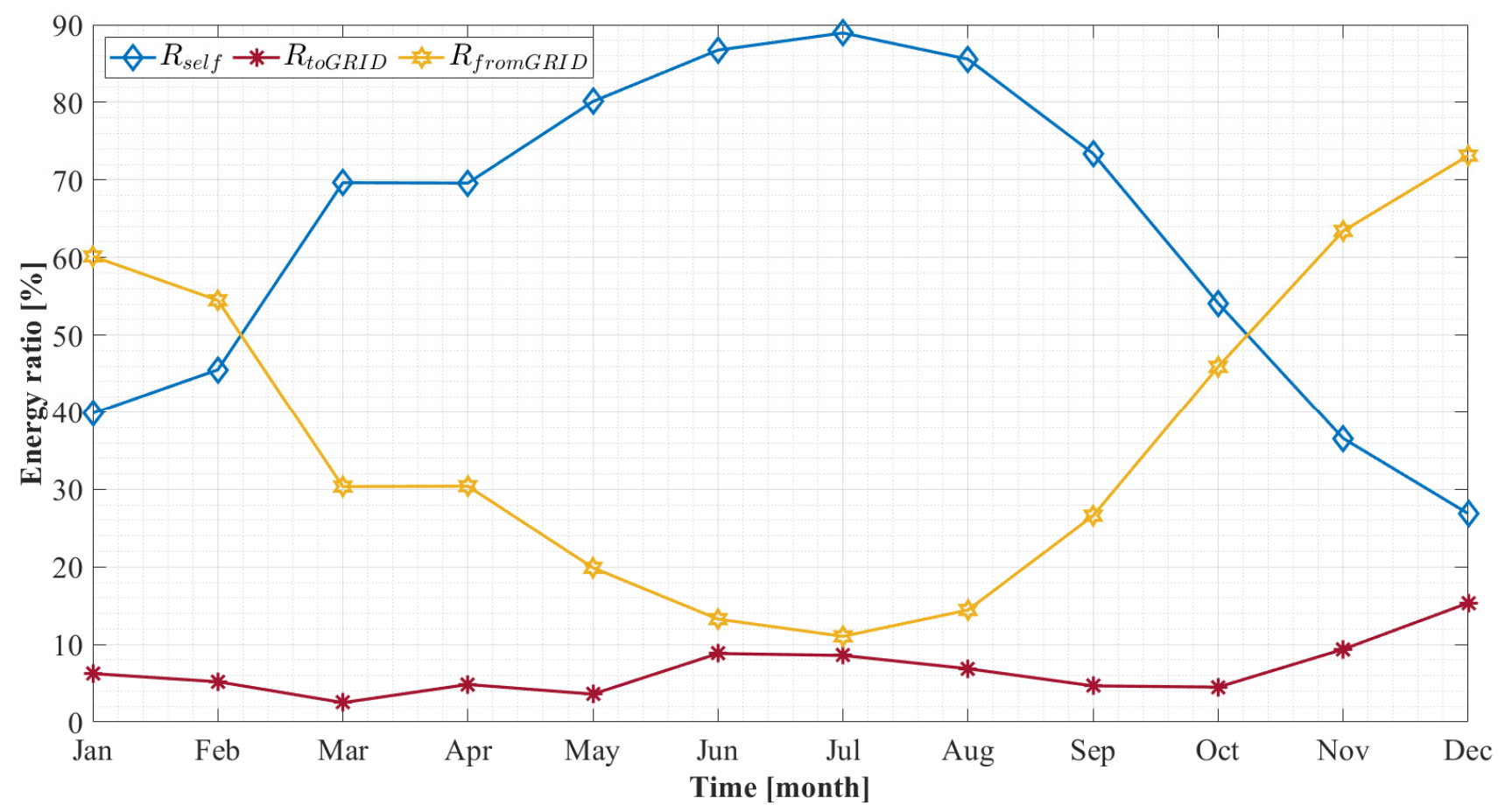

Figure 9. Energy ratios. 
In the summer season, the energy provided by the SOFC, $E_{e l, f r o m S O F C}$, is high, and the self-consumption of the system shows the maximum values. During the summer season (April-September), $R_{\text {self }}$ matches up to $70 \%$. This result is justified by the fact that the electric energy demand is almost constant during the year, but it highlights the profitability of the proposed system. The electric energy needed for the compression work, $E_{e l, c o m p}$, is always negligible compared to the electric load. By comparing the electricity supplied to the SOEC, $E_{e l, t o S O E C}$, and the electricity supplied to the PV system, $E_{e l, P V}$, a dual trend can be detected. During the winter season, when the solar irradiation is lower, $E_{e l, t o S O E C}$ follows the same trend shown for $E_{e l, P V}$. During the summer season, when the solar radiation is higher, according to the designed control strategy, the surplus energy is not supplied to the SOEC, and $E_{e l, t o S O E C}$ is almost constant. In this case, the electricity is directly supplied to the grid and $E_{e l, t o G R I D}$ is higher.

Figure 9 shows that the electricity fraction from the PV, which is supplied to the grid, increases in the summer period, as expected from Figure 8. More specifically, since the PV energy dramatically decreases in the winter period, the electricity fraction supplied to the grid increases. The majority of the load is met by the coupled PV + SOC + storage system in summer period, when the coverage rises up to $90 \%$ of the total energy demand.

\subsubsection{Yearly Results}

In Table 4 reports the results obtained by the dynamic simulation considering one year of operation. According to the presented data, the overall efficiency of the SOC is 0.47 , which is fairly high with respect to values available in literature. This result is due to the adopted control managing the cell, which allows the cell to always work in the optimal field of operating conditions.

Table 4. Main results of the yearly dynamic simulation.

\begin{tabular}{ccl}
\hline Parameter & Value & Unit \\
\hline$E_{\text {el,toSOEC }}$ & 43.25 & MWh/year \\
$E_{e l, f r o m S O F C}$ & 20.39 & MWh/year \\
$E_{\text {el,comp }}$ & 4.65 & MWh/year \\
$E_{\text {el,toGRID }}$ & 5.92 & MWh/year \\
$E_{e l, \text { fromGRID }}$ & 34.73 & MWh/year \\
$E_{e l, \text { toTANK }}$ & 45.23 & MWh/year \\
$E_{e l, f r o m T A N K}$ & 44.43 & MWh/year \\
$E_{\text {el,self }}$ & 58.67 & MWh/year \\
\hline
\end{tabular}

The energy supplied to the grid is about $6.3 \%$ of the total energy provided by the PV field, whereas the energy withdrawn from the grid is $37.2 \%$ of the energy demand. These results confirm that the goal of the proposed system is reached since the energy exchanged with the national grid is strongly reduced. The total self-consumption of the system reaches $62.8 \%$, which means that the proposed system is fairly energy-independent. In Table 5, the main results from the thermoeconomic analysis are reported.

The results of the proposed system (PS) are compared to the reference system (RS), in which the overall energy demand of the dwelling is supposed to be met by the grid. The high profitability of the PS is shown by the relevant energy savings, with a PES of $69 \%$. The coupling of the PV with the SOC and $\mathrm{H}_{2}$ storage system determines a decrease of the PE consumption from 203.05 to $75.50 \mathrm{MWh} /$ year. As a consequence, the $\mathrm{CO}_{2}$ equivalent emissions also undergo a strong reduction. Furthermore, the operating costs are strongly decreased since, in the PS, the energy withdrawn by the grid is by far lower than in the RS. Moreover, the surplus electricity is sold to the grid, and a further saving is obtained. 
Table 5. Results from the thermoeconomic analysis.

\begin{tabular}{cccc}
\hline & & RS & PS \\
\hline$P E$ & {$[$ MWh/year] } & 203.05 & 75.50 \\
$P E S$ & {$[\%]$} & - & 69 \\
$C O_{2}$ & {$\left[\mathrm{t}_{\mathrm{CO} 2} /\right.$ year] } & 44.83 & 16.67 \\
$\Delta C O_{2}$ & {$[\%]$} & - & 69 \\
$C$ & {$[\mathrm{k} € /$ year] } & 16.81 & 5.90 \\
$\Delta C$ & {$[\mathrm{k} € /$ year] } & - & 10.92 \\
$\Delta C$ & {$[\%]$} & - & 65 \\
$I N V$ & {$[\mathrm{k} \epsilon]$} & - & 110.13 \\
$S P B$ & {$[$ years] } & - & 10.1 \\
$N P V$ & {$[\mathrm{k} €]$} & - & 42.70 \\
$P I$ & {$[\%]$} & - & 39 \\
\hline
\end{tabular}

The proposed shows interesting results with a total investment cost of $110.13 \mathrm{k} €$, and $S P B$ of 10.1 years. The NPV, calculated on the basis of 25 years of life, is equal to $42.70 \mathrm{k} €$. In conclusion, the economic profitability of the investment is $39 \%$.

\subsubsection{Parametric Analysis}

The results shown in the previous section demonstrate the relevant SPB of the proposed system. The thermoeconomic analysis shows that the economic profitability of the system is not encouraging. This is also due to an unoptimized selection of components capacities, mainly for the case of the storage tank. As a matter of fact, a tank of $1 \mathrm{~m}^{3}$ volume and 200 bar of maximum pressure can store the energy produced by the SOEC for $13 \mathrm{~h}$ of nominal operating conditions.

Figure 10 shows the results from the parametric analysis of the tank size, ranging from 25 bar to 200 bar of maximum pressure. The curves are referred to three different volumes of the storage, that are $0.50,0.75$, and $1 \mathrm{~m}^{3}$.
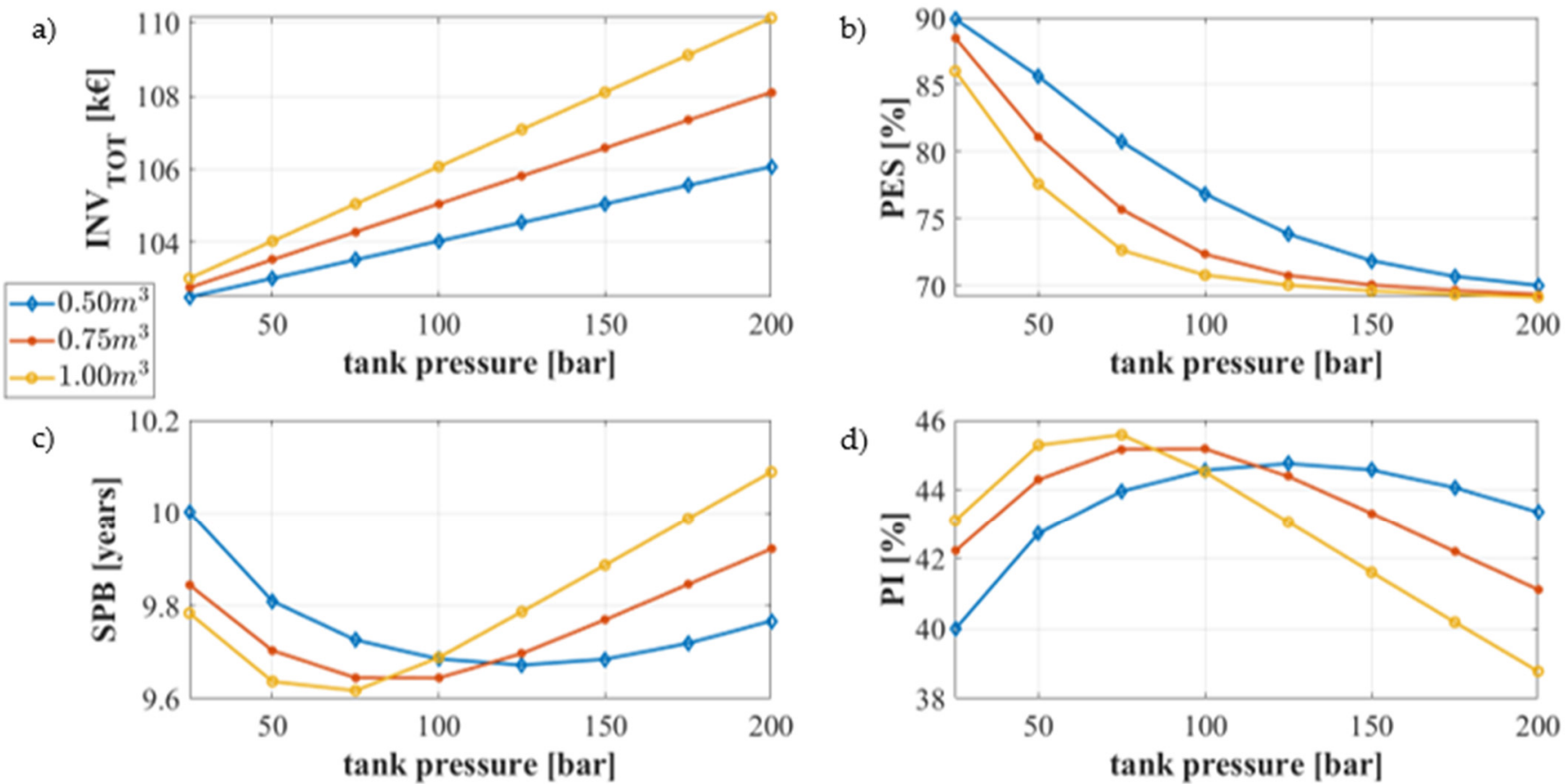

Figure 10. Parametric analysis of the hydrogen storage system: (a) total capital costs, (b) primary energy saving, (c) simple payback, (d) profit index, as a function of the maximum storage pressure. 
The capital cost of the system is the sum of two terms. The constant term is represented by the plant capital costs, in particular PV and SOC systems. The linearly increasing term is the storage cost, which is proportional to the maximum capacity. The storage cost is per unit of $\mathrm{kg}$ of hydrogen stored.

The higher the tank capacity and pressure, the higher the amount of energy that can be stored and the greater the energy self-consumed by the plant. At the same time, the increase of the tank capacity causes a reduction of the surplus electricity exported to the grid. Note that $1 \mathrm{kWh}$ produced by the PV field and delivered to the grid corresponds to $0.96 \mathrm{kWh}$ exported to the grid, due to the regulator/inverter efficiency. Conversely, $1 \mathrm{kWh}$ produced by the PV field and delivered to the SOEC and stored into the tank corresponds to about $0.80 \mathrm{kWh}$ self-consumed by the plant, because of the efficiency of the electrolyzer, fuel cell, and compressor.

These figures justify the reduction of the PES as the tank capacity increases.

From the economic point of view, the self-consumed electricity plays a significant role, much more than the one played by the electricity exported to the grid: $j_{\text {el fromGRID }}=0.20 € / \mathrm{kWh}$ vs. $j_{e l, t o G R I D}=0.05 € / \mathrm{kWh}$. As mentioned before, the higher the tank capacity and maximum pressure, the higher the amount of energy stored in the tank.

However, $S P B$ curves in Figure 10 exhibit a minimum that represents a threshold value. A further increase in tank capacity would not increase the self-consumed energy since the system is not able to fill the tank beyond that value. For example, for a $1 \mathrm{~m}^{3}$ tank, the system achieves the best profitability for a tank maximum pressure equal to 75 bar. A further increase of the maximum tank pressure only determines an increase of the storage capital cost, without increasing the exploitation of the storage charge/discharge capacity.

The same trend can be detected for the PI graph. Once a value of $1 \mathrm{~m}^{3}$ of capacity and 75 bar of maximum pressure are selected, wider energy storage leads to a lower profitability of the system. In this case, the difference is significant since the optimal solution shows a PI by $46 \%$, and it can only decrease, even below $40 \%$.

\section{Conclusions}

This work proposes a dynamic simulation of a coupled photovoltaic-solid-oxide cellhydrogen storage system developed in TRNSYS. The novelty of this work is the integration in TRNSYS of a reversible solid-oxide cell model developed and validated in MATLAB ${ }^{\circledR}$ that allows one to calculate the dynamic operating conditions of the cell. The hybrid system model simulates the coupling of a dwelling load with a photovoltaic field energy production. On the one hand, this system provides electricity to the electrolyzer when there is a surplus with respect to the demand. On the other hand, when there is a deficit in the energy production with respect to the load, the electricity is provided by the fuel cell, when the storage is sufficiently charged. The system proposed is compared to a reference one in which the electricity load of the dwelling is entirely satisfied by the grid. Results from the dynamic simulation and the thermoeconomic and parametric analyses show that:

- The overall efficiency of the system is very high compared to the other solid-oxide cell systems since the operating field is always in the optimal range of the cell. The global efficiency is, in fact, almost $47 \%$;

- The storage system effectively reduces the peaks of the load since the interchanges with the grid are strongly reduced. In particular, the electricity sent to the grid is approximately $7 \%$ of the total PV production;

- The parametric analysis shows that the system leads to a primary energy saving of $73 \%$ within a simple pay-back period lower than 10 years. The system is also economically profitable, revealing a profit index of $46 \%$.

The system here proposed gives some interesting perspectives on the hydrogen storage systems. Future analyses will also consider the thermal flow rates due to the reversible solid-oxide cell system. In this case, the energy saving should be even greater, and an exergy analysis could be provided. Furthermore, the integration of this system in a more complex power to gas plant could be interesting for the innovation of hybrid energy systems. 
Author Contributions: Conceptualization: F.C., F.L.C., L.C., M.D.d., and M.V.; methodology: F.C., F.L.C., L.C., M.D.d., and M.V.; software: F.C., F.L.C., L.C., M.D.d., and M.V.; supervision: F.C., F.L.C., L.C., M.D.d., and M.V.; writing-original draft: F.C., F.L.C., L.C., M.D.d., and M.V.; writing-review and editing: F.C., F.L.C., L.C., M.D.d., and M.V. All authors have read and agreed to the published version of the manuscript.

Funding: No external fundings were provided for this work.

Institutional Review Board Statement: Not applicable.

Informed Consent Statement: Not applicable.

Data Availability Statement: Not applicable.

Conflicts of Interest: The authors declare no conflict of interest. The corresponding author confirms that all the other authors have read and approved the manuscript and no ethical issues are involved.

\section{Nomenclature}

\begin{tabular}{|c|c|}
\hline GHG & Greenhouse gases \\
\hline SOC & Solid oxide cell \\
\hline HSS & Hydrogen storage system \\
\hline $\mathrm{P} 2 \mathrm{H}$ & Power to hydrogen \\
\hline SMR & Steam methane reforming \\
\hline RES & Renewable energy system \\
\hline CSTR & Continuously stirred tank reactor \\
\hline PEM & Proton exchange membrane \\
\hline AEC & Alkaline electrolyzer cell \\
\hline AFC & Alkaline fuel cell \\
\hline DU & Degassing unit \\
\hline COD & Chemical oxygen demand \\
\hline NHES & Nuclear hybrid energy system \\
\hline ASR & Area specific resistance $\left(\mathrm{w} / \mathrm{cm}^{2}\right)$ \\
\hline PV & Photovoltaic \\
\hline SOFC & Solid oxide fuel cell \\
\hline CCS & Carbon capture and storage \\
\hline SOEC & Solid oxide electrolyzer cell \\
\hline OLR & Organic loading rate $(\mathrm{kgCOD} /(\mathrm{L} \mathrm{d}))$ \\
\hline PE & Primary energy (MWh) \\
\hline SPB & Simple pay back (years) \\
\hline NPV & Net present value $(\mathrm{k} €)$ \\
\hline PI & Profit index (\%) \\
\hline PES & Primary energy saving (\%) \\
\hline LCOE & Levelized cost of energy $(€)$ \\
\hline$n$ & Molar flow rate $(\mathrm{mol} / \mathrm{s})$ \\
\hline$i$ & Current density $\left(\mathrm{mA} / \mathrm{cm}^{2}\right)$ \\
\hline $\mathrm{p}$ & Pressure (bar) \\
\hline $\mathrm{T}$ & Temperature $\left({ }^{\circ} \mathrm{C}\right)$ or $(\mathrm{K})$ \\
\hline $\mathrm{V}$ & Voltage (V) \\
\hline $\mathrm{F}$ & Faraday's constant $(\mathrm{C} / \mathrm{mol})$ \\
\hline $\mathrm{R}$ & Gas constant $(\mathrm{J} / \mathrm{mol} \mathrm{K})$ \\
\hline $\mathrm{P}$ & Power $(k W)$ \\
\hline $\mathrm{E}$ & Energy (kWh) or (MWh) \\
\hline \multicolumn{2}{|c|}{ Greek symbols } \\
\hline$\alpha$ & Symmetry factor (adim.) \\
\hline$\eta$ & efficiency (adim.) \\
\hline
\end{tabular}




\section{References}

1. Masson-Delmotte, V.; Zhai, P.; Pirani, A.; Connors, S.L.; Péan, C.; Berger, S.; Caud, N.; Chen, Y.; Goldfarb, L.; Gomis, M.I.; et al. (Eds.) Climate Change 2021: The Physical Science Basis. Contribution of Working Group I to the Sixth Assessment Report of the Intergovernmental Panel on Climate Change; IPCC: Geneva, Switzerland; Cambridge University Press: Cambridge, UK, 2021.

2. Bistline, J.; Blanford, G.; Mai, T.; Merrick, J. Modeling variable renewable energy and storage in the power sector. Energy Policy 2021, 156, 112424. [CrossRef]

3. Hemmati, R.; Ghiasi, S.M.S.; Entezariharsini, A. Power fluctuation smoothing and loss reduction in grid integrated with thermal-wind-solar-storage units. Energy 2018, 152, 759-769. [CrossRef]

4. Greiml, M.; Fritz, F.; Kienberger, T. Increasing installable photovoltaic power by implementing power-to-gas as electricity grid relief-A techno-economic assessment. Energy 2021, 235, 121307. [CrossRef]

5. Abdin, Z.; Zafaranloo, A.; Radiee, A.; Merida, W.; Lipinski, W.; Khalilpour, L.R. Hydrogen as an energy vector. Renew. Sustain. Energy Rev. 2020, 120, 109620. [CrossRef]

6. Zhang, C.; Wang, J.; Ren, Z.; Yu, Z.; Wang, P. Wind-powered $250 \mathrm{~kW}$ electrolyzer for dynamic hydrogen production: A pilot study. Int. J. Hydrogen Energy 2021, 46, 34550-34564. [CrossRef]

7. Pein, M.; Neumann, N.C.; Venstrom, L.J.; Vieten, J.; Roeb, M.; Sattler, C. Two-step thermochemical electrolysis: An approach for green hydrogen production. Int. J. Hydrogen Energy 2021, 46, 24909-24918. [CrossRef]

8. Parmar, K.R.; Pant, K.; Roy, S. Blue hydrogen and carbon nanotube production via direct catalytic decomposition of methane in fluidized bed reactor: Capture and extraction of carbon in the form of CNTs. Energy Convers. Manag. 2021, 232, 113893. [CrossRef]

9. Ali Khan, M.H.; Daiyan, R.; Neal, P.; Haque, N.; MacGill, I.; Amal, R. A framework for assessing economics of blue hydrogen production from steam methane reforming using carbon capture storage \& utilisation. Int. J. Hydrogen Energy 2021, 46, $22685-22706$.

10. Yu, M.; Wang, K.; Vredenburg, H. Insights into low-carbon hydrogen production methods: Green, blue and aqua hydrogen. Int. J. Hydrogen Energy 2021, 46, 21261-21273. [CrossRef]

11. Rivera, X.C.S.; Topriska, E.; Kolokotroni, M.; Azapagic, A. Environmental sustainability of renewable hydrogen in comparison with conventional cooking fuels. J. Clean. Prod. 2018, 196, 863-879. [CrossRef]

12. Thapa, B.S.; Neupane, B.; Yang, H.-S.; Lee, Y.-H. Green hydrogen potentials from surplus hydro energy in Nepal. Int. J. Hydrogen Energy 2021, 46, 22256-22267. [CrossRef]

13. Rabiee, A.; Keane, A.; Soroudi, A. Technical barriers for harnessing the green hydrogen: A power system perspective. Renew. Energy 2020, 163, 1580-1587. [CrossRef]

14. Ni, M.; Leung, M.K.; Leung, D.Y.; Sumathy, K. A review and recent developments in photocatalytic water-splitting using TiO ${ }_{2}$ for hydrogen production. Renew. Sustain. Energy Rev. 2007, 11, 401-425. [CrossRef]

15. Schmidt, O.; Gambhir, A.; Staffell, I.; Hawkes, A.; Nelson, J.; Few, S. Future cost and performance of water electrolysis: An expert elicitation study. Int. J. Hydrogen Energy 2017, 42, 30470-30492. [CrossRef]

16. Wang, S.; Li, W.; Fooladi, H. Performance evaluation of a polygeneration system based on fuel cell technology and solar photovoltaic and use of waste heat. Sustain. Cities Soc. 2021, 72, 103055. [CrossRef]

17. Holmes-Gentle, I.; Tembhurne, S.; Suter, C.; Haussener, S. Dynamic system modeling of thermally-integrated concentrated PV-electrolysis. Int. J. Hydrogen Energy 2021, 46, 10666-10681. [CrossRef]

18. Cao, Y.; Parikhani, T. A solar-driven lumped SOFC/SOEC system for electricity and hydrogen production: $3 E$ analyses and a comparison of different multi-objective optimization algorithms. J. Clean. Prod. 2020, 271, 122457. [CrossRef]

19. Martín-García, Í.; Rosales-Asensio, E.; González-Martínez, A.; Bracco, S.; Delfino, F.; de Simón-Martín, M. Hydrogen as an energy vector to optimize the energy exploitation of a self-consumption solar photovoltaic facility in a dwelling house. Energy Rep. 2020, 6, 155-166. [CrossRef]

20. Al-Khori, K.; Bicer, Y.; Koç, M. Comparative techno-economic assessment of integrated PV-SOFC and PV-Battery hybrid system for natural gas processing plants. Energy 2021, 222, 119923923. [CrossRef]

21. Elberry, A.M.; Thakur, J.; Santasalo-Aarnio, A.; Larmi, M. Large-scale compressed hydrogen storage as part of renewable electricity storage systems. Int. J. Hydrogen Energy 2021, 46, 15671-15690. [CrossRef]

22. Okundamiya, M. Size optimization of a hybrid photovoltaic/fuel cell grid connected power system including hydrogen storage. Int. J. Hydrogen Energy 2020, 46, 30539-30546. [CrossRef]

23. Wang, Q.; Liu, C.; Luo, R.; Li, X.; Li, D.; Macián-Juan, R. Thermo-economic analysis and optimization of the very high temperature gas-cooled reactor-based nuclear hydrogen production system using copper-chlorine cycle. Int. J. Hydrogen Energy 2021, 46, 31563-31585. [CrossRef]

24. Ho, A.; Mohammadi, K.; Memmott, M.; Hedengren, J.; Powell, K.M. Dynamic simulation of a novel nuclear hybrid energy system with large-scale hydrogen storage in an underground salt cavern. Int. J. Hydrogen Energy 2021, 46, 31143-31157. [CrossRef]

25. Caglayan, D.G.; Weber, N.; Heinrichs, H.U.; Linßen, J.; Robinius, M.; Kukla, P.A.; Stolten, D. Technical potential of salt caverns for hydrogen storage in Europe. Int. J. Hydrogen Energy 2020, 45, 6793-6805. [CrossRef]

26. Karacavus, B.; Aydın, K. Hydrogen production and storage analysis of a system by using TRNSYS. Int. J. Hydrogen Energy 2020, 45, 34608-34619. [CrossRef]

27. Wang, C.; Chen, M.; Liu, M.; Yan, J. Dynamic modeling and parameter analysis study on reversible solid oxide cells during mode switching transient processes. Appl. Energy 2020, 263, 114601. [CrossRef] 
28. Hajimolana, S.A.; Hussain, M.A.; Daud, W.A.W.; Soroush, M.; Shamiri, A. Mathematical modeling of solid oxide fuel cells: A review. Renew. Sustain. Energy Rev. 2011, 15, 1893-1917. [CrossRef]

29. Zeng, Z.; Qian, Y.; Zhang, Y.; Hao, C.; Dan, D.; Zhuge, W. A review of heat transfer and thermal management methods for temperature gradient reduction in solid oxide fuel cell (SOFC) stacks. Appl. Energy 2020, 280, 115899. [CrossRef]

30. Somano, V.; Ferrero, D.; Santarelli, M.; Papurello, D. CFD model for tubular SOFC directly fed by biomass. Int. J. Hydrogen Energy 2021, 46, 17421-17434. [CrossRef]

31. Pianko-Oprych, P.; Jaworski, Z.; Kendall, K. Cell, Stack and System Modelling. In High-Temperature Solid Oxide Fuel Cells for the 21st Century, 2nd ed.; Kendall, K., Kendall, M., Eds.; Academic Press: Cambridge, MA, USA, 2016; Chapter 13; pp. 407-460.

32. Sundén, B. Modeling approaches for fuel cells. In Hydrogen, Batteries and Fuel Cells; Sundén, B., Ed.; Academic Press: Cambridge, MA, USA, 2019; Chapter 10; pp. 167-202.

33. Kalogirou, S.A. Designing and Modeling Solar Energy Systems. In Solar Energy Engineering, 2nd ed.; Kalogirou, S.A., Ed.; Academic Press: Cambridge, MA, USA, 2014; Chapter 11; pp. 583-699.

34. Calise, F.; Cappiello, F.L.; Dentice d'Accadia, M.; Vicidomini, M. Dynamic modelling and thermoeconomic analysis of micro wind turbines and building integrated photovoltaic panels. Renew. Energy 2020, 160, 633-652. [CrossRef]

35. Bellemare, C.; Labelle, D. Hourly meteorological data files adapted for main frame computer programs and for microcomputer programs. In Intersol Eighty Five; Bilgen, E., Hollands, K.G.T., Eds.; Pergamon: Oxford, UK, 1986; pp. $2420-2423$.

36. Moran, M.J. Fundamentals of Engineering Thermodynamics, 6th ed.; Wiley: Hoboken, NJ, USA, 2008.

37. Calise, F.; Cappiello, F.L.; Dentice, M.; Vicidomoni, M. Concentrating photovoltaic/thermal collectors coupled with an anaerobic digestion process: Dynamic simulation and energy and economic analysis. J. Clean. Prod. 2021, 311, 127363. [CrossRef]

38. Singh, S.P.; Ohara, B.; Ku, A.Y. Prospects for cost-competitive integrated gasification fuel cell systems. Appl. Energy 2021, 290, 116753. [CrossRef]

39. Carr, S.; Premier, G.C.; Guwy, A.J.; Dinsdale, R.M.; Maddy, J. Hydrogen storage and demand to increase wind power onto electricity distribution networks. Int. J. Hydrogen Energy 2014, 39, 10195-10207. [CrossRef]

40. Calise, F.; Cappiello, F.L.; D’Accadia, M.D.; Vicidomini, M. Energy efficiency in small districts: Dynamic simulation and technoeconomic analysis. Energy Convers. Manag. 2020, 220, 113022. [CrossRef] 